\title{
Rural tourism development using ecotourism as a model of community empowerment in Cireundeu indigenous village, Cimahi, West Java, Indonesia
}

\author{
Deru R Indika ${ }^{1, *}$, Nike Vonika ${ }^{1}$
}

${ }^{1}$ Department of Management and Business, Faculty of Economics and Business, Universitas Padjadjaran, Indonesia
${ }^{*}$ Corresponding author: deru.indika@unpad.ac.id

\begin{abstract}
Ecotourism, as a concept of sustainable tourism, is used in the development of rural tourism. Ecotourism concerns about the conservation of nature and culture, the participation of local residents, the transfer of knowledge to visitors, and the small scale of tourism to preserve the environment capability. The process of community empowerment through the development of rural tourism in Cireundeu was triggered by a discourse about the reactivation of Leuwi Gajah landfill. Objections to the landfill have been voiced, but they did not manage to cause the landfill to be inactive. Using a qualitative approach, this study describes the process of community empowerment through the development of rural tourism by raising the potentials of Cireundeu as an indigenous village. Cireundeu's culture is still maintained by its community. For instance, cassava is still consumed as a primary food, local arts and ritual Also ceremonies are still held. Cireundeu society is a subject in the process of empowerment by acquiring inputs from various parties.
\end{abstract}

Keywords - ecotourism, community development, rural tourism.

\section{INTRODUCTION}

Tourism activities have so far caused various issues. According to the Ministry of Tourism and Creative Economy (Kemenparekraf, 2011), one of the issues is about community empowerment. This is because the management and process of getting profit from tourism destination disregards the local communities. The investors who develop an area to become a tourism area sometimes overlook local communities. In fact, they are important elements to be engaged in tourism development, especially the tourism destination that promotes natural resource. So, the local people usually get benefit only from selling handicrafts, food and souvenirs in small scale.

In addition, tourism activities also often cause environmental damage. This is because both the managers and tourists have less awareness to take responsibility for protecting the environment. The high number of visitor to a tourism destination has also become a trigger for the destruction of environment.

Considering the environment sustainability is an important factor in the process of community empowerment because the preservation of the natural environment will automatically maintain the survival of the community. This is confirmed by Adi (2008), stating that the sustainability in a relatively underdeveloped country such as Indonesia tends to focus on the sustainability of development programs, and frequently the element of environment preservation does not become a main element to be discussed.

In relation, the term ecotourism was born as a concept in the world of tourism emphasizing the principle of sustainability that promotes conservation and provides benefits to local communities. The importance of involving the local communities in the planning, implementation and management of a tourism destination is based on the idea that local communities have the knowledge about the nature and culture. Local wisdom adhered by the local people in their culture and nature is an asset that should be maintained and preserved. This is used as a way of managing a tourism destination. In addition, local wisdom also has a potential value and selling point as a tourism attraction (Damanik and Weber, 2006).

One of the tourism destinations in West Java which develops ecotourism by promoting community empowerment is Cireundeu village, which is a traditional village located in the administrative area of Cimahi, West Java. The indigenous people of Cireundeu are the people who consume cassava rice (as their staple food), commonly called rasi. This custom passes down from generation to generation by tabooing rice consumption. 
As a result, Cireundeu village has ever became the center of attention when the Food Security Bureau promoted food diversification and made Cireundeu village as an example of society who could live healthily without eating rice. This bureau made Cireundeu as an icon of food security because of Cireundeu's independence in the staple food they grow, process, and consume. With its peculiarity, Cireundeu became much visited by tourists. The uniqueness of Cireundeu also appears in the way of life of its people who firmly hold their traditional values, inherited from their ancestors. The visitors who come to Cireundeu are government, academia, students, media and public.

As a tourism destination for people in any level, Cireundeu is an asset and has the potential that can be explored and developed to be a tourism destination which empowers people for their welfare. The visiting tourists shall bring both good and bad changes to Cireundeu. The negative impact could be a value shifting in Cireundeu due to the increasing contact with tourists, or the presence of environmental pollution because there are many tourists coming. To that end, the principles of ecotourism by emphasizing the value of education in the program are aimed at developing Cireundeu to be a tourism destination.

Local people in Cireundeu once served tourists as in any other tourism destinations, but the service performed was only guest welcoming and not with the orientation as travel service providers. Later, Cireundeu community began to make changes in welcoming each visit. Tourists who came to Cireundeu started to be better served. The change made by community of Cireundeu in welcoming tourists was for a purpose. This was done as an effort of the community to silence a discourse of Leuwi Gajah landfill reactivation located not far from Cireundeu village. The people of Cireundeu rejected the landfill because they did not want their lives disrupted by the landfill. Therefore, the community developed the rural tourism. Through the rural tourism, the community hoped to maintain and preserve the environment. Based on the above explanation, the questions in this study are as follows: 1) How is the process of community empowerment program in developing rural tourism in Cireundeu village, West Java?, 2) What are the factors that support and hinder the process of community empowerment program in developing rural tourism in Cireundeu village, West Java?

Ecotourism is essentially defined as a form of tourism that is responsible for the preservation of the natural area, provides economic benefits and maintains the cultural integrity of local communities (Fandeli, 2000). Ecotourism is not a concept developed for a promotion to increase sale of a tourism destination but as a mechanism that supports the sustainability of tourism destination, both environmental sustainability and community sustainability in terms of social, economic and cultural aspect (Nugroho, 2011).

In the management of ecotourism, the local communities should have a huge influence in utilizing their environment. Regarding to this, there is the concept of community empowerment which means a scheme that shows the strength and ability of the communities to (a) satisfy their basic needs so that they have the freedom; (b) reach the productive resources that would allow them to increase income and obtain goods and services they need; and (c) participate in the development process and the in making decisions that may affect them (Suharto, 2010: 58).

Ecotourism, as a concept of travel tourism that includes education elements, preserves the natural and cultural heritage, promotes the participation of local communities, is seen as a service that should be managed professionally. Therefore, the business sectors of ecotourism are required to have professional management, including: a) specific marketing in the tourism destination, marketing strategy is an important aspect to attract visitors all over the world, b) skills and services which are intensive, c) involvement of local communities in guiding and translating the attraction, $d$ ) government policy which protects the environment and cultural assets, e) capability development of the local communities. The local communities and the environment are unified in ecotourism (Nugroho, 2011).

The pattern of ecotourism is aimed at minimizing the negative impact on the environment and local culture, improving the income of local communities and providing conservation values. Some key aspects of ecotourism are; the number of visitors is limited or regulated to suit the capacity of the environment and socio-cultural aspect, the tourism pattern in eco-friendly (conservation value), the tourism pattern is cultural and custom friendly (value of education and tourism), it directly helps the economy of local community (economic value), and the initial capital required for the infrastructure is not much (value of society participation and economy). The pattern of community-based ecotourism recognizes the right of local communities to manage tourism activities in the area they traditionally own or just as the managers (Directorate of Tourism Products, 2009).

In relation to the ecotourism as well as the development of an area to be a tourism destination, some previous researches can be traced. Among them is the research of Susanto (2009) entitled "Analysis of Progress of Ecotourism Planning in Ciliwung river Segment I". In 
this study, ecotourism is directed to the conservation of Ciliwung river through rafting tourism. This study concluded that rafting activities can create jobs for people who live nearby the area. In addition to increasing the income of local community, ecotourism activities also give contribution to the DKI Jakarta Provincial Government as a source of Local Revenue (PAD) through ticket fee. Thus, the tourism sector can affect the welfare of community.

The research of Yara (2011), conducted in Karst Citatah region Padalarang, illustrates that the mining activity in the area had a negative impact on the environment. However, there are two potential areas which have not been exposed to the exploitation of the mining. These areas can be saved, namely Mount Masigit and Cave Pawon. These areas have the potential of ecology, geology, archaeology, history and culture. Therefore, ecotourism was chosen as the more conventional tourism is considered to neglect the environmental sustainability.

Another study conducted by Hudisaputra (2012) illustrates that extractive activities tend to damage coastal areas of Kiluan Bay. Such activities decrease environmental capability. Therefore, a non-extractive activity that is environmentally friendly and sustainable is needed. Ecotourism is the right choice for protecting this environment. Various natural potentials can be developed into tourism attractions. But in the development process, there are many things that must be prepared to make Kiluan Bay ready as a tourism destination. These activities are infrastructure improvement, coordination among stakeholders and quality improvement of local human resources who are the providers of services in the future.

Of the three studies illustrated above, it can be taken into account that the conservation of environment whose sustainability has been disrupted can be done by developing ecotourism as a form of tourism that is responsible for environmental sustainability. Although there were empowerment and participation of local communities in the ecotourism undertaken in those regions, they are not enough. In addition, those studies illustrate that ecotourism was developed with the purpose mainly for natural conservation. While in the declaration of Quebec (2002), ecotourism can also be developed for cultural conservation that emphasizes community participation through community empowerment.

\section{METHOD}

This research is a descriptive study using a qualitative approach. This research studies and observes the community empowerment program of indigenous people of Cireundeu village in the process of development of the area to be an ecotourism destination. A qualitative approach is a process of investigation and understanding of the phenomenon from the perspective studied, then the results of the investigation are presented in narrative form (Creswell, 2009). According to Neuman (2006), qualitative data includes documenting real events, recording what people say (with words, body gestures, and tone), observing the environment specifically, studying the written document or explaining the visual image. This research was conducted in Cireundeu village, Cimahi, West Java. The location was chosen because Cireundeu is the only indigenous village in West Java which develops tourism activities through the concept of ecotourism. In addition to it, the ecotourism offered promotes a cultural conservation, environmental conservation and community development, aimed at achieving well-being society as a whole. The research was conducted for four months starting from literature study to report writing. The study began in April 2013 to July 2013.

\section{Technique of Selecting Informants}

Informants were chosen selectively in order to provide relevant information. The purposive sampling was used as the sample selection technique. Based on the informant selection technique used in this study, the information was obtained from the parties involved in ecotourism development in Cireundeu. The informant criteria in this study are: 1) the communities, they are the people conducting community empowerment program in ecotourism development in Cireundeu. 2) the government, they are the Section Head of Agriculture of Cooperatives Department, Industrial department, Trade and Agriculture department of Cimahi municipal government and the Head of RW 10 Leuwi Gajah, Cireundeu indigenous village, 3) the academicians, namely partners from LPPM (Institute for Research and Community Service) Universitas Padjadjaran (UNPAD) and LPPM Universitas Jendral Ahmad Yani (UNJANI).

\section{Technique and Data Analysis}

The data analysis of qualitative data is through several stages. According to Creswell (2009), the stages of data analysis are processing and preparing data for analysis, reading the whole picture, analyzing in more detail by coding the data, showing how the description and these themes will be represented in a qualitative report, and finally interpreting the data which can be done by comparing the findings with the theory or concept used. 


\section{Technique in Improving Research Quality}

To improve the research quality, the data obtained were tested through triangulation. It is a powerful strategy to improve the research quality. Triangulation was done in data and data sources. Triangulation of data is a method where the data collected in various ways are compared (for example, data from structured interviews, participant observation, life histories). Triangulation of data sources was conducted to maximize the range of data that may contribute to understanding the concept. It is based on the importance of variation in time, space, observed people and interviews.

\section{RESULTS}

Based on the findings from the field, the empowerment through rural tourism development in the Cireundeu indigenous village was triggered by the reactivation discourse of Leuwi Gajah landfill. Based on the concept of empowerment by Shardlow (in Adi, 2002) and selfsufficiency by Soetomo (2012), it was found that the community within their own selves can define what their needs really are. In this case of Cireundeu village community, they tried to face the issue together by making negotiations to inhibit the reactivation of the landfill.

The initial process made by the community was to encourage all citizens to engage in the rejection of landfill reactivation. To gather support from all communities, the people conducted continuous discussions by involving all elements of society in determining the fate of their village. As a result, the society fully supported the rejection of the landfill around Cireundeu village. But there were some groups, especially the non-indigenous people who did not fully support this refusal.

The community can do assessment individually (through community leaders or any member of a society) or in groups (Adi 2002). The community of Cireundeu village assessed the area together with their leaders by identifying the problems, needs and potentials.

The identified problems faced by the people of Cireundeu village are; the existence of Leuwi Gajah landfill can impair the quality of life of Cireundeu people, and they also felt that they were quite weak for rejecting the landfill because the landfill is legitimately owned by the government. In fact, the community expressed that their need is to live comfortably in a healthy environment and away from the landfill. Having identified the problems and the needs which have been mapped, the community can explore their asset as potential to solve problems and meet their needs. The assessment resulted in assets of Cireundeu village which have the potential to overcome problems and meet their needs. Cireundeu village is known as an indigenous village where people have the habit of eating cassava as the staple food. This cassava eating habit, where the cassava is grown, processed and consumed, makes Cireundeu independent village selfsufficient in their food, so Cireundeu village was honored as an icon of food security in West Java. As a traditional village, Cireundeu village has cultures which are still alive and maintained until now (e.g. folklore, local arts and ritual ceremonies).

Having identified the problems, needs and potentials, the community made planning for empowerment process. The results of the field assessment are the two alternative programs that would be conducted to overcome the problems. First, the people would still perform denial of the landfill by negotiating with the government. Second, the people would use the concept of tourism as a form of activity for rejecting the landfill.

With the potential that they have, the people then chose the second alternative. In the beginning of the implementation of community empowerment process, the community changed the way they welcomed every guest. The guests were treated like tourists. So, the guests who came were served better. The visitors were served the typical meal of Cireundeu village made from cassava. The cooperation among residents had also improved since every citizen had the role to welcome the visitors. As expressed by Suharto (2010), community empowerment refers to the ability of communities to participate in the development process and making decision that affects their lives. Each visitor is welcomed together, for example there are people who greet the guests at the bale and people who cook in the kitchen to prepare Cireundeu traditional foods. The tourism activity was first carried out in a simple way like welcoming the guests at bale.

In its development, Cireundeu village acquired a lot of input from outside parties such as from private industry, government and university as seen from the field observation. The large number of inputs and support from outside parties is consistent with the concept of community empowerment proposed by Ross (1967) stating that one approach to the community empowerment is called "inner resources approach". This approach emphasizes the importance of encouraging communities to identify their needs and desires, and work cooperatively with government and other institutions. The guidance from university was in the form of cassava processing based on experiments that have been conducted by the students. The cassava processing groups consisting of mothers of Cireundeu village were 
also formed. In addition to cassava processing activities, the management of tourism service is also important in welcoming the guests coming to Cireundeu village. Visitors who come individually or in small groups can experience and enjoy a tour at Cireundeu village by attending the everyday life of people in Cireundeu village.

The facilities such as public toilets, a clean and comfortable environment as well as homestay for visitors are also important. The homestay program is based on the finding from the field that some houses can provide a room to be a place for visitors to stay.

The empowerment is seen from the people's readiness in welcoming visitors. It appears from the findings that initially people were shy to interact with visitors. But then people eventually got used to welcoming the guests and having more confidence.

The people in Cireundeu village also realized that they need more effort in developing and managing the tourism services. Therefore, the revenues from the tourism services were saved in the village cash so that they are not dependent on outside parties in developing their own communities.

Furthermore, the evaluation phase is the regulatory process of the people on the programs. Evaluation is done by the people in Cireundeu village soon after they finished welcoming visitors. The people who have a role in welcoming the guests usually still gather at bale for reviewing their services offered to the guests. The results of the evaluation will be the input for improvement in the future. In addition, people in Cireundeu village also perform evaluation together with all the people on a program they are doing. From the results of the evaluation, the people also saw another potential that could be developed into a tourism village. This is the traditional games for children given that there are many children coming to the village. So, the traditional children' games can be taught to the children coming (guests). Then community also required the division of roles in the management of the rural tourism. Thus, they established the organizational structure where each position contributes to the success of Cireundeu as a rural tourism area.

\section{DISCUSSION}

Based on the evaluation, there was a need for structure in the management of a rural tourism in accordance with one of the elements of self-reliant community. This is in the form of social institution or pattern of activity that is institutionalized in the community carrying out daily activities.
The empowerment program conducted by the people of Cireundeu is empowerment as a process. According to Adi (2012), empowerment as a process is a continuous process throughout the life of a person (ongoing process). This is also true in a society where a community empowerment process will not end with the completion of a program, implemented either by government or non-government. The process of empowerment will last as long as the community still exists and the people still try to empower themselves. In the case of Cireundeu village, there is no termination stage in the process of empowerment because the community empowerment will take place continually. Moreover, the people in Cireundeu village are the subject of the empowerment activities. The initiative for empowerment came from the people of Cireundeu themselves so that the empowerment is a process that will last as long as the community still exists.

The sustainability of community empowerment process was done by trying to embrace all people in Cireundeu village especially the non-indigenous people who initially did not support the rejection of reactivation of Leuwi Gajah landfill. This effort is made so that the nonindigenous people and indigenous people have one vote in rejecting the landfill. They were also invited to participate more in the development of rural tourism in Cireundeu village.

If linked to the Declaration of Quebec (2002), ecotourism formulation includes some efforts to: a) contribute actively to the conservation of nature and culture. In the development of rural tourism in Cireundeu village, the conservation of culture emphasized is to preserve the cultural heritages, namely cassava eating habit and other cultural heritages offered to visitors, b) participate local people in the planning, construction and operation of tourism activities and let them enjoy prosperity. The management of rural tourism in Cireundeu village involves the entire community in the planning, development and operation. The success of empowerment in the development of this rural tourism is determined by the high participation of citizens in running the program, c) transfer the knowledge about cultural and natural heritage to visitors. The tourism activities that can be done by visitors are to practice how to make rasi and feel the life as the people of Cireundeu, d) form the independent tourism or small tour groups. The number of visitor to Cireundeu village is approximately 500 people per month. This number is still in accordance with Cireundeu environmental 
capability. It can be seen that the visitors who come to Cireundeu village do not make negative changes to the environment of Cireundeu.

\section{CONCLUDING REMARK}

The process of community empowerment through the program of rural tourism in Cireundeu is triggered by the agreement of entire community to reject the reactivation of Leuwi Gajah landfill. The phase of assessment was conducted in participatory way where the people of Cireundeu identified their problems, needs and potentials owned. From the identification with the community, the problem faced by the people of Cireundeu was the reactivation of Leuwi Gajah landfill. This indeed can damage their environment. In fact, the people of Cireundeu want a comfortable and healthy life away from the landfill. Therefore, in addressing the issue, the people of Cireundeu explored the potential that they have. As a traditional village, Cireundeu has cultural assets, namely cassava eating habit (as its staple food), folklore, local arts and ceremonies. Those are the ancestral heritage still run by the community until now. Based on the assessment results, the people of Cireundeu established a joint program that is developing their village to be a rural tourism. This program was selected on the ground that if Cireundeu village is developed to be a tourism destination, it is not possible for the location to be a landfill, too.

In the implementation process of rural tourism, the people of Cireundeu acquired a lot of inputs from various parties, namely government and universities. The inputs from these parties were collaborated by the people of Cireundeu to be the activities that they developed as tourism services offered to visitors. The empowerment is a process that continues throughout the life of Cireundeu village community. The process of empowerment in Cireundeu village is an empowerment that came from the people themselves. The communities together make choice to achieve their future goals. In the development of rural tourism, the people of Cireundeu did not only perform environmental empowerment but also economic and social empowerment. The process of empowerment in Cireundeu shows that the people of Cireundeu could determine their future goal in accordance with their wishes. As the empowerment came from the community, the participation level in this empowerment is high. Every member of community realized that the process is based on the problem and the need of the community.
The empowerment in Cireundeu village is categorized as the empowerment as a process. This empowerment lasts as long as the people of Cireundeu still exist, or as long as the people can find solution for their own problems.

\section{ACKNOWLEDGEMENT}

This paper is written supervised by Kania Saraswati H, S.Sos, M.Kesos and elders of Cireundeu village and supporting from Dewitapa program

\section{REFERENCE}

Adi, Isbandi Rukminto. Pemikiran-pemikiran dalam peradaban kesejahteraan sosial. Fakultas Ekonomi UI. 2002

Adi, Isbandi Rukminto. Intervensi komunitas: pengembangan masyarakat sebagai upaya pemberdayaan masyarakat. Jakarta: Rajawali Pers. 2008

Creswell, John W. Qualitative inquiry and research design. United States of America: Sage Publication. 2009

Damanik, Janianton dan Helmut F. Weber. Perencanaan ekowisata: dari teori ke aplikasi. Yogyakarta: Andi. 2006

Fandeli, C. Pengusahaan ekowisata. Yogyakarta: Fakultas Kehutanan Universitas Gajah Mada. 2000

Neuman, Lawrence. Social research methods. Qualitative and quantitative approaches. United State of America: Pearson International Edition. 2006

Nugroho, Iwan. Ekowisata dan pembangunan berkelanjutan. Yogyakarta: Pustaka Pelajar. 2011

Ross, Murray. Community organization. Theory, principle and practice. New York: Crowed company. 1967

Soetomo. Keswadayaan masyarakat, manifestasi kapasitas masyarakat untuk berkembang secara mandiri. Yogyakarta: Pustaka Pelajar. 2012

Suharto, Edi. Membangun masyarakat memberdayakan rakyat. Bandung: Refika Aditama. 2010

Susanto, Eko Gumilar. Tesis: analisis progress perencanaan ekowisata sungai ciliwung segmen I. Depok: FEUI. 2005

Hudisaputra, Arif Kurniawan.. Pengelolaan wilayah pesisir teluk kiluan, kabupaten tanggamus melalui pengembangan ekowisata. Bandung: Magister Ilmu Lingkungan Universitas Padjadjaran. 2012

Yara, Roby Alam.. Studi pengembangan ekowisata di kawasan karst citatah padalarang bandung (gunung 
masigit dan goa pawon). Bandung: Magister Ilmu Lingkungan Universitas Padjadjaran. 2011

Direktorat Produk Pariwisata Direktorat Jenderal Pengembangan Destinasi Pariwisata dan WWF Indonesia.. Prinsip dan kriteria ekowisata berbasis masyarakat. 2009

International Year of Ecotourism, Quebec declaration on ecotourism, Quebec City. 2002

Kementerian Pariwisata dan Ekonomi Kreatif. Laporan akuntabilitas kinerja kementerian pariwisata dan ekonomi kreatif tahun 2010. Jakarta: Biro Perencanaan dan Organisasi Sekretariat Jenderal Kementerian Pariwisata dan Ekonomi Kreatif. 2011
Kementerian Pariwisata dan Ekonomi Kreatif. Laporan akuntabilitas kinerja kementerian pariwisata dan ekonomi kreatif tahun 2011. Jakarta: Biro Perencanaan dan Organisasi Sekretariat Jenderal Kementerian Pariwisata dan Ekonomi Kreatif. 2012.

Krefting, Laura. Rigor in qualitative research: the assessment of trustworthiness., The American Journal of Occupational Therapy. 1990.

Undang-undang No. 17 tahun 2007 mengenai Rencana Pembangunan Jangka Panjang Nasional tahun 2005-2025 